\title{
Geneeskunde: meer dan een beroepsopleiding
}

Tien juni jl. werd het verslag van de onderwijsvisitatie aangeboden aan de Vereniging van Universiteiten (VSNU). Sinds 1992, toen de eerste visitatie plaatsvond, was dit de derde keer dat de acht geneeskunde-opleidingen in Nederland werden beoordeeld. Net als de vorige keren werd ook nu de visitatie verricht door een speciaal daarvoor door de VSNU ingestelde commissie, waarin verschillende medische disciplines waren vertegenwoordigd. De beoordeling van de opleiding vond plaats aan de hand van een door de opleiding opgestelde 'zelfstudie', handleidingen voor het onderwijs, stageverslagen, studiegidsen, gesprekken met een groot aantal personen die bij het onderwijs zijn betrokken, het bekijken van bibliotheek, onderwijsruimten, computerzalen en andere faciliteiten, et cetera. In dit nummer van het Tijdschrift voor Medisch Onderwijs gaan de voorzitter van de Visitatiecommissie Geneeskunde, prof. dr. H.J. Huisjes, en één van de commissieleden, mw. prof. dr. J. Denekens, nader in op de bevindingen van de commissie. ${ }^{1}$

De commissie concludeert dat er sinds de vorige visitatie in 1997 veel in gunstige zin is verbeterd. De meeste universitaire centra hebben ingrijpende curriculumherzieningen doorgevoerd of zijn daar nog mee bezig. Hiermee hebben ze met name op het gebied van didactische werkvormen hun opleiding aanzienlijk gemoderniseerd. Natuurlijk zijn er ook onderdelen van de opleidingen die nadere aandacht behoeven, maar de grote lijn van het visitatierapport is dat "het niveau van het onderwijs zonder meer aanvaardbaar is te noemen."
Visitaties zoals deze zijn van groot belang. Ofschoon de commissie waarschuwt voor de beperking van vergelijkende scores, is dit voor de acht universitaire medische centra toch een mogelijkheid om de kenmerken en de kwaliteit van de eigen opleiding af te zetten tegen die van de andere opleidingen. Rekening houdend met de beperkingen van zo'n benchmarking, wordt heden ten dage een vergelijkend oordeel in de gezondheidszorg en bij opleidingen gezien als een nuttig instrument om het eigen product te verbeteren. ${ }^{2-4}$ Maar haast nog meer dan het resultaat van een visitatie, is het visitatieproces een wezenlijk onderdeel van de kwaliteitszorg. Het schrijven van de zelfstudie is daarbij de belangrijkste drijfveer. Een zorgvuldige beschrijving van de huidige situatie van de opleiding, het vergelijken van die situatie met wat er beoogd was en tenslotte het formuleren van beleidsvoornemens vormen de basis van een reflectie op de eigen opleiding. In feite heb je daar het oordeel over de producten van de collegae niet voor nodig. En als het goed is, levert zo'n reflectie een realistisch beeld op van de sterke en zwakke punten van de opleiding, waar een visitatiecommissie niet veel meer aan behoort te kunnen toevoegen.

Eén van de 'verbeterpunten' die de visitatiecommissie in haar rapport noemt, is de academische vorming. Critici noemen de opleiding geneeskunde wel eens een beroepsopleiding. De aard van het vak maakt dat de basisarts over een grote hoeveelheid praktische kennis en vaardigheden moet beschikken. Als in de opleiding de aan- 
dacht daartoe beperkt blijft, is er inderdaad sprake van een beroepsopleiding. De opleiding tot basisarts is echter breder dan alleen maar 'een vak leren'. In alle opleidingen behoren academische vaardigheden tot de eindtermen van de opleiding. Wetenschappelijke vorming is een belangrijk onderdeel daarvan. Maar ook andere aspecten van academische vorming, zoals bij voorbeeld reflectie op het eigen handelen, reflectie op onze 'westerse' manier van het uitoefenen van de geneeskunde in vergelijking met die van andere culturen, diversiteit, ethiek en wetenschapsfilosofie krijgen aandacht in de meeste opleidingen. De visitatiecommissie concludeert dat er op dit punt positieve veranderingen zichtbaar zijn, maar pleit sterk voor een nog sterker beleid op dit terrein. Mijns inziens is dit één van de belangrijkste aanbevelingen van de commissie. De hamvraag daarbij is natuurlijk wat we precies onder academische vorming verstaan. Sommige technische universiteiten, zeker die in de Verenigde Staten, hebben in hun onderwijsprogramma's al lange tijd onderwijsmodules opgenomen die gericht zijn op een brede en algemene vorming. ${ }^{5}$ Met de toevoeging van onderwerpen die buiten het directe vakgebied vallen en gericht zijn op algemene vorming, wordt in feite een opleidingsconcept gebruikt waarvan het nut al in de klassieke oudheid beproefd is. De programma's van die techni- sche universiteiten kunnen ons gemakkelijk tot voorbeeld dienen. Maar wellicht geeft de Oxford Dictionary bij één van de drie beschrijvingen van het begrip 'academisch' ons de belangrijkste leidraad voor de invulling van het onderwijs in academische vaardigheden: "not relevant to practical affairs, of theoretical interest only."6 De uitdaging voor de komende jaren is om artsen op te leiden die niet alleen hun vak adequaat kunnen uitoefenen en zich bij de keuze van handelen laten leiden door evidence-based medicine principes, maar die ook voldoende vaardigheden hebben die hen met recht tot een academicus maken.

\section{Jan Borleffs}

\section{Literatuur}

1. Huisjes HJ, Denekens J. De onderwijsvisitatie geneeskunde 2003. Tijdschrift voor Medisch Onderwijs 2004;23(3):127-132.

2. Kingma JH. Presteren in de gezondheidszorg. Med Contact 2004;59:769.

3. Kemers-Gels M, Nienhuijs SW, Barendregt WB, Bruggink EDM, Stobbe LJA. Stafleden op rapport. Med Contact 2004;59:273-5.

4. Kremer J. Landelijke IVF cijfers 1996 t/m 2002. Website Nederlandse Vereniging voor Obstetrie en Gynaecologie. www.nvog.nl.

5. Derkse W. Vruchtbare 'nutteloosheid': het belang van algemene vorming in de context van beroepsgerichte academische opleidingen. Tijdschrift voor Medisch Onderwijs 2004;23:57-63.

6. Hornby AS. Oxford advanced dictionary of current English. Oxford University Press; 1995. 